\title{
Relationships of bradyrhizobia from Platypodium and Machaerium (Papilionoideae: tribe Dalbergieae) on Barro Colorado Island, Panama
}

\author{
Matthew A. Parker and Alexandra Lunk
}

\begin{abstract}
Author for correspondence: M. A. Parker. Tel: +1 607777 6283. Fax: + 16077776521.
\end{abstract} e-mail: mparker@binghamton.edu

Department of Biological Sciences, State University of New York, Binghamton, NY 13902-6000, USA

\begin{abstract}
Enzyme electrophoresis and rRNA sequencing indicated that root nodule bacteria from the canopy tree Platypodium elegans and the lianas Machaerium milleflorum and Machaerium arboreum on Barro Colorado Island, Panama, were highly diverse on a local scale. A total of 11 distinct multilocus genotypes [ETs (electrophoretic types)] was found among the 33 isolates analysed. On average, ETs differed from one another at $74 \%$ of the 11 enzyme loci assayed, and separate nodules on a single host individual were often occupied by genetically divergent ETs. Certain ETs were sampled multiple times from both Platypodium and Machaerium, suggesting a lack of specificity toward the two legume genera. Within the intervening sequence (IVS) region in the $5^{\prime}$ end of 235 rRNA, seven ETs had a length variant similar to that of Bradyrhizobium japonicum USDA 110, and the other four ETs had an IVS region 26-28 bp shorter. Parsimony analysis of both partial 235 rRNA and nearly full-length 165 rRNA sequences indicated that all Platypodium and Machaerium isolates were related to $B$. japonicum rather than Bradyrhizobium elkanii. The 16S rRNA sequence of one isolate was $>99 \%$ similar to that of $B$. japonicum USDA 110 , and the closest known relatives for other isolates were Philippine bradyrhizobia from the legumes Stylosanthes and Samanea.
\end{abstract}

Keywords: Bradyrhizobium japonicum, 16S rRNA, 23S rRNA, tropical biodiversity

\section{INTRODUCTION}

Even though Neotropical forests are one of the main centres of legume biodiversity (Raven \& Polhill, 1981), very little is known about root nodule bacteria associated with these plants. Field surveys have helped to quantify the prevalence of nodulation in different taxa (Faria et al., 1984; Souza Moreira et al., 1992), but relatively few studies have used nucleotide sequencing to assess relationships. 16S rRNA data reported for isolates from several genera of woody legumes in Brazil indicated that they were related to Bradyrhizobium elkanii (Dupuy et al., 1994; Laguerre et al., 1997; Lafay \& Burdon, 1998). However, for the vast majority of host taxa in tropical American forests,

Abbreviations: ET, electrophoretic type; IVS, intervening sequence.

The GenBank accession numbers for the $16 \mathrm{~S}$ rRNA sequences of isolates Pe1-3, Pe4 and Mm1-3 are AF159436-AF159438, respectively. the diversity and phylogenetic affinities of nodule bacteria have not been investigated.

In this study, we analysed the relationships of bradyrhizobia from two genera of the papilionoid tribe Dalbergieae growing on Barro Colorado Island, Panama. Barro Colorado Island is a biological preserve in Gatun Lake in the Panama Canal covered by a semi-evergreen moist tropical forest, much of which has received little disturbance for the past several hundred years (Foster \& Brokaw, 1996). Platypodium elegans is a canopy tree found in areas of the island covered by both old and young forest (Croat, 1978; Augspurger, 1983). The genus Platypodium includes only two species (Gentry, 1993), but it has a wide geographic range in the Neotropics and can be relatively common (Croat, 1978). The genus Machaerium has about 125 species of small trees or lianas widely distributed throughout tropical America, with one species extending to the coast of West Africa (Rudd, 1977; Bastos, 1988). We sampled root nodules 
from several individuals of $P$. elegans and $M$. milleflorum, and from one individual of $M$. arboreum, because juvenile plants of these taxa are relatively common in the forest understorey, and they have distinctive vegetative morphology which makes them easy to recognize. Bacterial isolates were characterized by isozyme allele profiles using starch gel electrophoresis (Selander et al., 1986) and by rRNA sequence analysis. We focused on a region in the $5^{\prime}$ end of $23 \mathrm{~S}$ rRNA which contains an intervening sequence (IVS) that is cleaved and removed during RNA processing (Selenska-Pobell \& Evguenieva-Hackenberg, 1995; Evguenieva-Hackenberg \& Selenska-Pobell, 1995). The IVS region is highly polymorphic among Rhizobiaceae, and we therefore felt that it could be a useful marker for analysing closely related bacterial strains. To confirm phylogenetic hypotheses derived from partial 23S rRNA sequences, we also obtained nearly full-length $16 \mathrm{~S}$ rRNA sequences from three representative strains.

\section{METHODS}

Isolate sampling. Root nodule bacteria were collected from six individuals of $P$. elegans, five individuals of $M$. milleflorum, and one individual of $M$. arboreum (Table 1). Isolates were named by an abbreviation of the host's name followed by a number designating an individual plant. Nodules were sampled from small juvenile plants by carefully excavating around the base of the stem until roots with attached nodules were located. For half of the plant individuals sampled, only a single nodule was obtained per plant. From the remaining plants, 2-7 nodules were collected. Isolates from separate nodules on the same host individual were designated by a dash and a number following the plant number (Table 1). All plants sampled were $<1.8 \mathrm{~km}$ apart from one another on the northeast side of Barro Colorado Island. $\mathrm{Pe} 1, \mathrm{Pe}, \mathrm{Mm} 1$ and $\mathrm{Mm} 2$ grew $<12 \mathrm{~m}$ from one another in a single light gap. Pe5, Pe6 and Marb1 also occurred within one light gap $<10 \mathrm{~m}$ from each other. Mm3 and Mm4 grew $2 \mathrm{~m}$ apart, and were approximately $300 \mathrm{~m}$ from $\mathrm{Pe} 3$ and $\mathrm{Pe} 4$.

Nodules were washed and then stored in vials with calcium sulfate desiccant. Within 1 week, nodules were rehydrated in $0.04 \mathrm{M}$ sodium phosphate buffer $\mathrm{pH} 7 \cdot 0$, then surfacedisinfected in $3.2 \%$ sodium hypochlorite. One isolate was purified from each nodule as described previously (Spoerke et al., 1996). All isolates grew slowly on yeast-mannitol agar plates (colonies were not visible before $5 \mathrm{~d}$ ), suggesting that they were members of the genus Bradyrhizobium.

Enzyme electrophoresis. Bacterial isolates were grown in yeast-mannitol broth (Vincent, 1970) and enzymes were obtained from sonicated cells (Spoerke et al., 1996). Isolates were characterized by starch-gel electrophoresis at the following 11 enzyme loci: alcohol dehydrogenase (ADH), alanine dehydrogenase (ALA), butyrate esterase (EST), glucose-6-phosphate dehydrogenase (G-6), $\beta$-hydroxybutyrate dehydrogenase (HBD), isocitrate dehydrogenase (IDH), malic enzyme (ME), malate dehydrogenase (MDH), phosphoglucose isomerase (PGI), 6-phosphogluconate dehydrogenase (6-P) and shikimate dehydrogenase (SDH). HBD, IDH, MDH and 6-P were resolved on buffer 11 of Soltis et al. (1983) (sodium citrate pH 7.0 electrode buffer and histidine. $\mathrm{HCl}$ gel buffer). ADH, ALA and SDH were resolved on buffer I of Selander et al. (1986) (Tris/borate $\mathrm{pH}$

Table 1. Bacterial strains used in this study

\begin{tabular}{|c|c|c|c|}
\hline Host individual & Origin* & Strains & ET \\
\hline \multirow[t]{3}{*}{ P. elegans 1} & Barbour Trail, BCI & Pe1-1, Pe1-3, Pe1-5 & 1 \\
\hline & & Pe1-2 & 2 \\
\hline & & Pe1-4 & 4 \\
\hline \multirow[t]{2}{*}{ P. elegans 2} & Barbour Trail, BCI & $\mathrm{Pe} 2-1$ to $\mathrm{Pe} 2-5$ & 1 \\
\hline & & Pe2-6 & 7 \\
\hline P. elegans 3 & Shannon Trail, BCI & Pe3-1, Pe3-2 & 10 \\
\hline P. elegans 4 & Shannon Trail, BCI & $\mathrm{Pe} 4$ & 11 \\
\hline P. elegans 5 & Fairchild Trail, BCI & Pe5 & 8 \\
\hline P. elegans 6 & Fairchild Trail, BCI & Pe6 & 7 \\
\hline \multirow[t]{3}{*}{ M. milleflorum 1} & Barbour Trail, BCI & Mm1-1 & 7 \\
\hline & & Mm1-2 & 3 \\
\hline & & Mm1-3 & 6 \\
\hline M. milleflorum 2 & Barbour Trail, BCI & $\mathrm{Mm} 2$ & 8 \\
\hline M. milleflorum 3 & Shannon Trail, BCI & Mm3-1 to Mm3-4 & 7 \\
\hline M. milleflorum 4 & Shannon Trail, BCI & $\mathrm{Mm} 4$ & 5 \\
\hline \multirow[t]{3}{*}{ M. milleflorum 5} & Laboratory Cove, BCI & Mm5-1, Mm5-6 & 8 \\
\hline & & Mm5-2 to Mm5-4, Mm5-7 & 7 \\
\hline & & Mm5-5 & 9 \\
\hline M. arboreum 1 & Fairchild Trail, BCI & Marb1 & 8 \\
\hline Glycine max & USA & B. japonicum USDA 110 & \\
\hline G. $\max$ & USA & B. elkanii USDA 94 & \\
\hline
\end{tabular}

* BCI, Barro Colorado Island, Panama. 
8.0). G-6, ME and PGI were resolved on Selander et al. (1986) buffer F (Tris/maleate $\mathrm{pH}$ 8.2) and EST was resolved on Selander et al. (1986) buffer G (potassium phosphate $\mathrm{pH}$ $7 \cdot 0$ ). Each isolate was characterized by its allelic profile for the 11 enzymes, and each unique multilocus genotype was designated an electrophoretic type (ET). Pairwise genetic distances between ETs were estimated by the proportion of enzyme loci at which allelic differences occurred. ETs were then clustered by the unweighted pair group method with arithmetic averages (UPGMA; Sneath \& Sokal, 1973).

DNA amplification and sequencing. DNA was purified from 18 isolates by the protocol of Wilson (1994). For reference, we also used Bradyrhizobium japonicum USDA 110 and $B$. elkanii USDA 94 (kindly provided by L. D. Kuykendall, USDA, Beltsville Agricultural Research Center-West, Beltsville, MD, USA). For PCR, $25 \mu \mathrm{l}$ reaction mixtures were used containing $10 \mathrm{mM}$ Tris buffer with $0 \cdot 1 \%$ Triton $\mathrm{X}-100,50 \mathrm{mM} \mathrm{KCl}, 1.5 \mathrm{mM} \mathrm{MgCl}, 0.2 \mathrm{mM}$ of each dNTP, $0.5 \mu \mathrm{M}$ of each primer, $0.5 \mu \mathrm{l}$ genomic DNA and $0.5 \mathrm{U}$ Taq polymerase. Tubes were incubated for $70 \mathrm{~s}$ at $94^{\circ} \mathrm{C}$ and then subjected to 34 cycles of $20 \mathrm{~s}$ at $94^{\circ} \mathrm{C}, 50 \mathrm{~s}$ at $58^{\circ} \mathrm{C}$ and $60 \mathrm{~s}$ at $72{ }^{\circ} \mathrm{C}$, with a final extension of $4 \mathrm{~min}$ at $72^{\circ} \mathrm{C}$. A $5^{\prime}$ portion of $23 \mathrm{~S}$ rRNA was amplified using primers 23Sup 115 and 23SrIII (Sterner \& Parker, 1999). These primers yield a $260 \mathrm{bp}$ DNA fragment in $B$. japonicum USDA 110 (GenBank accession no. Z35330). A $5 \mu \mathrm{l}$ aliquot of PCR product was run on a $1.9 \%$ agarose gel with a DNA size standard to analyse length variation. For seven isolates, a larger segment of DNA spanning this region was then sequenced on both strands beginning 62 bases from the $5^{\prime}$ end of the 23S rRNA gene using primers 23Sup6n and 23Sr\#2 (Sterner \& Parker, 1999; these amplify 496 bp in $B$. japonicum USDA 110). For three isolates, a 1410 bp portion of $16 \mathrm{~S}$ rRNA was amplified using primers fD1d and rPla (Parker, 1999). This fragment was sequenced on both strands using the following internal sequencing primers [Parker, 1999; numbers in parentheses indicate primer position relative to the Escherichia coli $\mathrm{rrnB}$ gene (Brosius et al., 1978)]: m5if (395-416), 5v2ir (420-438), 16smidf (774-795), al4r (890-911), 16cup (1069-1091) and m3ir (1178-1199). PCR-amplified DNA was sequenced using an Applied Biosystems model 310 automated sequencer with dyeterminator chemistry and the protocols recommended by the manufacturer.

Phylogenetic analyses. Sequences were first aligned using CLUSTAL w (Thompson et al., 1994), and then trees were constructed by maximum-parsimony using the PAUP software (version 4.0b1, from D. L. Swofford, Smithsonian Institution, Washington, DC, USA). Relationships were also analysed by the neighbour-joining algorithm (Saitou \& Nei, 1987), but results were virtually identical to the maximum-parsimony trees. To determine the degree of statistical support for branches in the phylogeny (Felsenstein, 1985), 1000 bootstrap replicates of each data set were analysed. For the $23 \mathrm{~S}$ rRNA region, data from Platypodium and Machaerium isolates were compared to reference sequences available for B. japonicum USDA 110 (GenBank accession no. Z35330), Bradyrhizobium sp. [Lupinus] strain DSM 30140 (X87283), B. elkanii USDA 94 (AF081266) and Bradyrhizobium strains jwc91-2 and ApT2 from the North American legumes Amphicarpaea and Apios, respectively (AF081262 and AF146821, respectively). Rhodopseudomonas palustris (X71839) was used as the outgroup (Sterner \& Parker, 1999). For 16S rRNA, data from Platypodium and Machaerium isolates were compared to the following Bradyrhizobium reference sequences (strains without formal names are identified by host legume genus in square brackets): B. japonicum strains USDA 6 (GenBank accession no. U69638) and USDA 110 (Z35330), strain DSM 30140 [Lupinus] (X87273), B. elkanii strains USDA 76 (U35000) and USDA 94 (D13429), strain 55S [Samanea] (D14507), strain 129 [Stylosanthes] (D14508; Oyaizu et al., 1993), Bradyrhizobium genomic species 'A' [Bossiaea] (Z94811; Lafay \& Burdon, 1998), Bradyrhizobium 'genomic species 'E' [Podolobium] (Z94814), Bradyrhizobium genomic species ' $\mathrm{H}$ ' [Goodia] (Z94816), Bradyrhizobium genomic species ' $\mathrm{P}$ ' [Daviesia] (Z94805), LMG 9514 [Lonchocarpus] (X70405; Dupuy et al., 1994). Several related genera of the $\alpha$-Proteobacteria were also included in the analysis: Azorhizobium caulinodans (X67221), Paracoccus denitrificans (X69159), Rhodobacter sphaeroides (D16424), Blastobacter denitrificans (S46917) and Rhodopseudomonas palustris (D25312). A. caulinodans was chosen as the outgroup because most $16 \mathrm{~S}$ rRNA phylogenies place it at a basal position relative to the other taxa (Willems \& Collins, 1993; Dupuy et al., 1994; Young \& Haukka, 1996).

Nodulation and nitrogenase activity. No seeds of Platypodium or Machaerium were available to use for inoculation studies. We thus used plants of Vigna unguiculata and Macroptilium atropurpureum, which are known to be nodulated by a broad range of tropical bradyrhizobia (Thies et al., 1991; Turk \& Keyser, 1992). Seven isolates representing different genotypes revealed by isozyme and rRNA sequence analyses were used to inoculate 3-4 plants of each species according to previously described procedures (Wilkinson et al., 1996). Seeds were surface-disinfected with $50 \%$ ethanol and then germinated. Seedlings were planted in pots using a Bradyrhizobium-free mixture of sand, perlite and potting soil, and then inoculated with approximately $10^{9}$ cells of a particular isolate grown in yeast-mannitol broth. Plants were grown in a greenhouse for $27 \mathrm{~d}$ with precautions to avoid bacterial contamination across inoculation treatments (Wilkinson et al., 1996). Uninoculated control plants grown simultaneously in the same room were found to be completely free of nodules. Plants were fertilized weekly with a nitrogen-free nutrient solution (Parker \& Wilkens, 1990). At harvest, nodule numbers were recorded, and each plant's root system was analysed for acetylene reduction activity using a Hewlett Packard 5890 series II gas chromatograph as described by Spoerke et al. (1996).

\section{RESULTS}

\section{Diversity and relationships inferred from multilocus enzyme electrophoresis (MLEE)}

Among the 33 isolates sampled from Platypodium and Machaerium, variation was detected at all 11 enzyme loci examined, with a mean of 4.7 alleles per locus (range, 2-7; Table 2). A total of 11 distinct ETs was detected. Seven of these ETs were represented by only a single isolate, whilst the remaining four ETs were recovered multiple times. The two most common ETs associated with $M$. milleflorum (ET7, ET8) were also observed in three isolates from P. elegans (Table 1). The sole isolate from $M$. arboreum also had the ET8 multilocus allele profile. The most common ET for $P$. elegans (ET1) occurred in 8 of the 11 nodules sampled from the Barbour Trail site, but was observed at no other locations for any of the host legumes.

An average linkage cluster analysis grouped the ETs 
Table 2. Allele profiles at 11 enzyme loci in 11 ETs of Bradyrhizobium isolates from Platypodium and Machaerium

\begin{tabular}{|c|c|c|c|c|c|c|c|c|c|c|c|c|c|}
\hline \multirow[t]{2}{*}{ ET } & \multicolumn{11}{|c|}{ Allele at indicated enzyme locus* } & \multicolumn{2}{|c|}{ No. of isolates } \\
\hline & ADH & ALA & EST & G-6 & HBD & IDH & ME & MDH & PGI & 6-P & SDH & Platypodium & Machaerium \\
\hline 1 & 1 & 2 & 2 & 2 & 1 & 1 & 6 & 2 & 1 & 1 & 3 & 8 & 0 \\
\hline 2 & 1 & 4 & 2 & 3 & 2 & 2 & 5 & 2 & 1 & 3 & 4 & 1 & 0 \\
\hline 3 & 1 & 4 & 2 & 3 & 2 & 2 & 6 & 2 & 1 & 3 & 1 & 0 & 1 \\
\hline 4 & 1 & 5 & 1 & 5 & 1 & 2 & 4 & 2 & 2 & 5 & 6 & 1 & 0 \\
\hline 5 & 1 & 0 & 3 & 3 & 4 & 4 & 1 & 2 & 2 & 6 & 5 & 0 & 1 \\
\hline 6 & 0 & 1 & 2 & 4 & 3 & 5 & 1 & 1 & 3 & 2 & 7 & 0 & 1 \\
\hline 7 & 2 & 3 & 4 & 1 & 3 & 3 & 1 & 2 & 3 & 4 & 2 & 2 & 9 \\
\hline 8 & 2 & 6 & 4 & 1 & 3 & 3 & 1 & 2 & 3 & 4 & 2 & 1 & 4 \\
\hline 9 & 2 & 6 & 4 & 1 & 3 & 3 & 1 & 2 & 3 & 6 & 2 & 0 & 1 \\
\hline 10 & 2 & 4 & 4 & 3 & 3 & 3 & 2 & 1 & 3 & 2 & 7 & 2 & 0 \\
\hline 11 & 2 & 4 & 4 & 3 & 3 & 3 & 3 & 1 & 3 & 2 & 7 & 1 & 0 \\
\hline
\end{tabular}

* Alleles are listed by relative anodal migration speed ( $1=$ slowest; null alleles are depicted by ' 0 '). ADH, alcohol dehydrogenase; ALA, alanine dehydrogenase; EST, butyrate esterase; G-6, glucose-6-phosphate dehydrogenase; HBD, $\beta$-hydroxybutyrate dehydrogenase; $\mathrm{IDH}$, isocitrate dehydrogenase; ME, malic enzyme; $\mathrm{MDH}$, malate dehydrogenase; PGI, phosphoglucose isomerase; 6-P, 6phosphogluconate dehydrogenase; SDH, shikimate dehydrogenase.

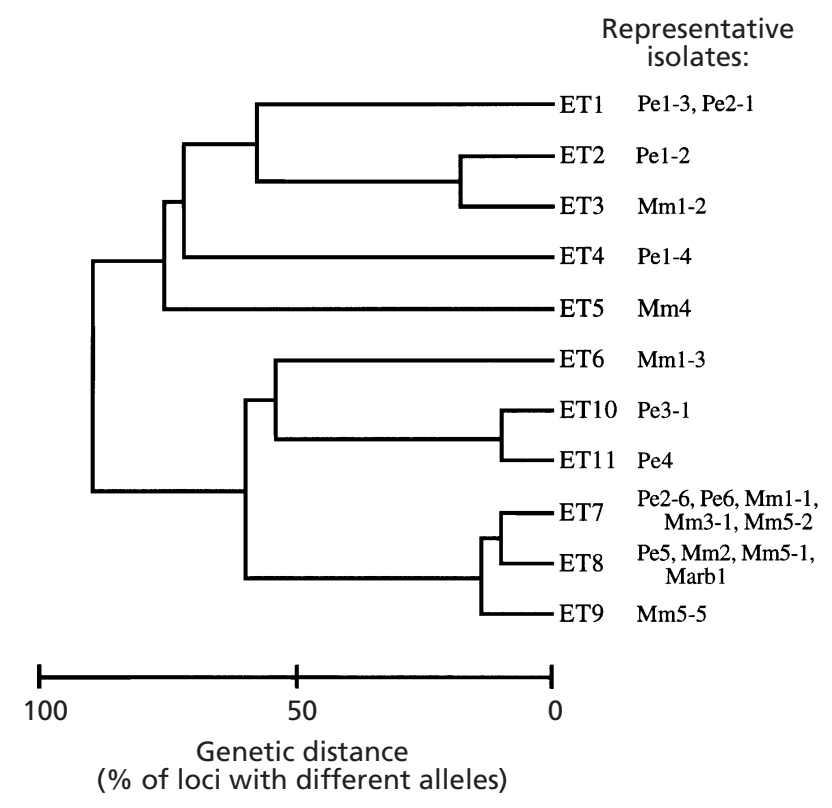

Fig. 1. Genetic relationships among 11 ETs of Bradyrhizobium isolates from Platypodium and Machaerium.

into several divergent lineages (Fig. 1). Isolates from both Platypodium and Machaerium were scattered throughout all groups, and showed little tendency to cluster according to host origin. Moreover, there was wide diversity among the bacterial isolates from separate nodules on the same individual host plant. For example, the three nodules sampled from plant Mm1 were extremely different from one another (ET3, ET6 and ET7), and highly divergent ETs were also found among the nodules sampled from plants Pe1 and $\mathrm{Pe} 2$.

\section{5 rRNA variation}

To further characterize relationships of these divergent genotypes, primers flanking a region in the $5^{\prime}$ portion of 23S rRNA that commonly shows length variation among taxa of Rhizobiaceae (Evguenieva-Hackenberg $\&$ Selenska-Pobell, 1995) were used to amplify DNA from representative isolates. Two basic length variants were detected. Isolates belonging to ET1, ET2, ET3 and ET6 had a smaller fragment that roughly corresponded to the size of DNA amplified from B. elkanii USDA 94 (232 bp). Strains belonging to ET4, ET5 and ET7-ET11 had a larger fragment that matched that of B. japonicum USDA 110 (260 bp).

A larger portion of $23 \mathrm{~S}$ rRNA spanning this region was sequenced in seven isolates. Alignment of the IVS region indicated that isolates were polymorphic for two long insertion/deletions together with two singlenucleotide-length variants. Four isolates with the longer length variant (Pe4, Mm4, Pe2-6 and Mm3-1) were very similar to $B$. japonicum USDA 110 , differing by only one single-nucleotide deletion and three or four base substitutions. Despite coming from different host legumes, the two isolates representing isozyme genotype ET7 (Pe2-6 and Mm3-1) were completely identical throughout the entire $496 \mathrm{bp}$ region sequenced. Among the three isolates with the shorter length variant (Pe1-3, Mm1-2, Mm1-3), all shared an apparently identical deletion of 12 bases corresponding to positions $168-179$ of the $B$. japonicum USDA 110 sequence. This condition was also seen in $B$. elkanii USDA 94 and numerous Bradyrhizobium isolates from the North American legumes Amphicarpaea, Apios and Desmodium (Sterner \& Parker, 1999; Parker, 1999). However, a second gap of 15 nucleotides in $B$. elkanii USDA 94 (corresponding to positions 215-229 of the $B$. japonicum USDA 110 sequence) was not 


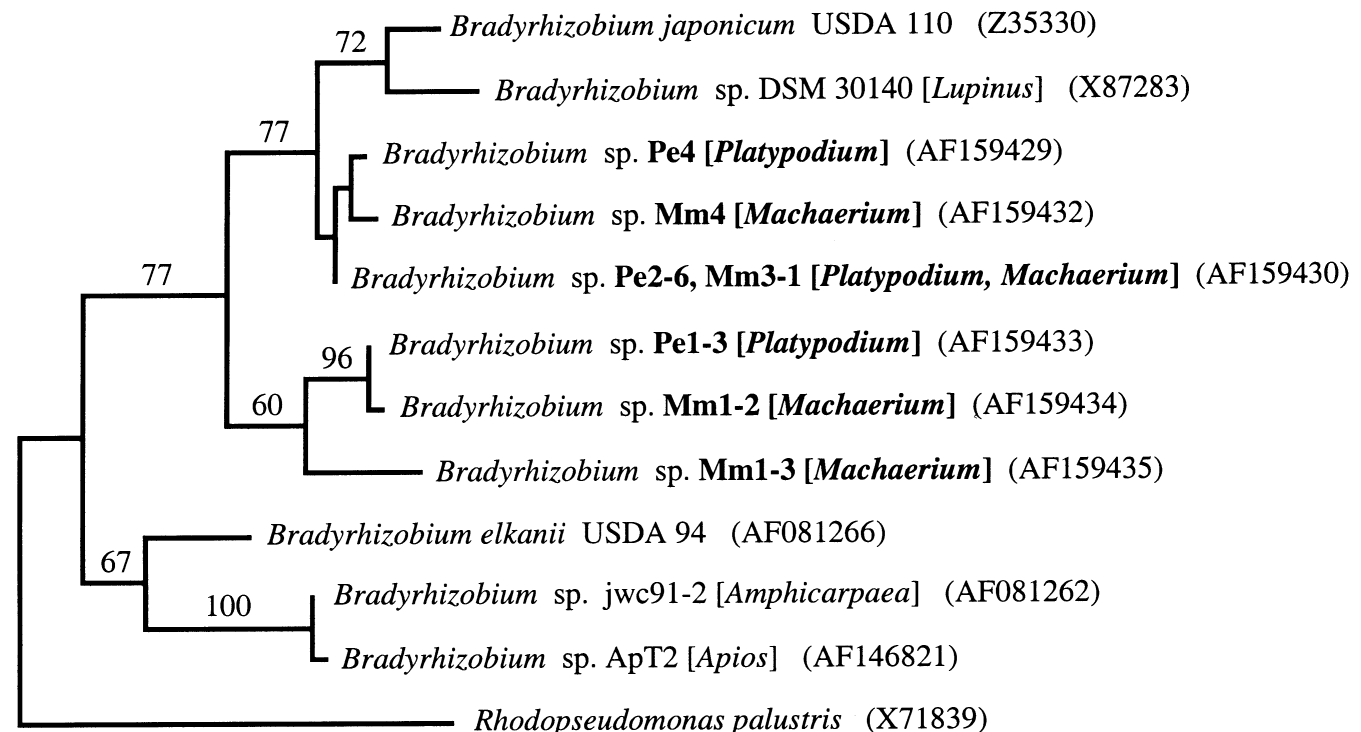

Rhodopseudomonas palustris (X71839)

$\overline{10 \text { steps }}$

Fig. 2. Parsimony tree for seven partial 235 rRNA sequences of Bradyrhizobium isolates from Platypodium and Machaerium (shown in bold). Numbers above branches are bootstrap percentages $(n=1000$ replicates). GenBank accession numbers are given after strain names.

precisely matched by any of the Platypodium or Machaerium isolates. Pe1-3 and Mm1-2 had a 13 bp gap in this area, whilst Mm1-3 had a 14 bp gap. Overall, these results indicate that the apparent $23 \mathrm{~S}$ rRNA IVS length similarity between $B$. elkanii and certain Panama isolates may reflect parallel evolution rather than common ancestry. Indeed, if data from the two large $23 \mathrm{~S}$ rRNA gap regions are omitted, a maximum-parsimony tree using the remaining portion of the 23S rRNA region sequenced (approx. $470 \mathrm{bp}$ ) grouped all Platypodium and Machaerium isolates into a clade together with $B$. japonicum USDA 110, with $B$. elkanii apparently forming a separate lineage (Fig. 2). However, the group consisting of all Panama isolates together with $B$. japonicum USDA 110 had only moderate bootstrap support $(77 \%)$. Relationships of selected isolates were therefore investigated further using 16S rRNA.

\section{$16 S$ rRNA variation}

Nearly full-length sequences were obtained for isolates Pe1-3, Mm1-3 and Pe4 (representing ET1, ET6 and ET11, respectively). Mm1-3 and Pe4 showed only three nucleotide differences out of $1410 \mathrm{bp}$ analysed, whilst Pe1-3 differed at 15-18 bases from the other two isolates. A search of $\alpha$-Proteobacteria sequences in GenBank identified other taxa whose 16S rRNA sequences were similar to each of these isolates (Fig. 3). Pe1-3 showed $>99 \%$ similarity to the 16S rRNA sequence of the non-symbiotic bacterium Blastobacter denitrificans (Willems \& Collins, 1992). B. japonicum USDA 110 and Bradyrhizobium genomic species 'A', which Lafay \& Burdon (1998) found to be widely distributed on shrubby legumes in Australia, also showed $>99 \%$ sequence similarity to Pe1-3 (Fig. 3). Photosynthetic stem-nodulating bradyrhizobia from Aeschynomene also show high 16S rRNA similarity to Blastobacter denitrificans (Wong et al., 1994), but these were not included in Fig. 3 because $<1100 \mathrm{bp}$ of sequence data were available compared to $>1400 \mathrm{bp}$ for the other taxa. The most similar sequences to Mm1-3 and Pe4 proved to be two Bradyrhizobium isolates from the Philippines studied by Oyaizu et al. (1993): 55S originated from the mimosoid tree Samanea saman, whilst strain 129 came from the herbaceous papiloinoid legume Stylosanthes guyanensis (tribe Aeschynomeneae). All three Platypodium and Machaerium isolates were grouped together with B. japonicum (USDA 110 and USDA 6) in a very high proportion of bootstrap replicates $(98 \%)$. Two isolates of $B$. elkanii (USDA 76 and USDA 94) formed a lineage that was distinct from the group that included the Platypodium and Machaerium isolates. A Brazilian isolate from Lonchocarpus costatus (papiloinoid tribe Tephrosieae; Dupuy et al., 1994) and an Australian isolate from Daviesia leptophylla (papilionoid tribe Mirbelieae; Lafay \& Burdon, 1998) also had 16S rRNA sequences that clustered with $B$. elkanii in a high proportion of bootstrap replicates, as seen in a previous analysis using the neighbour-joining method (Lafay \& Burdon, 1998).

\section{Symbiotic phenotypes}

Moderate to high numbers of nodules formed on most Vigna unguiculata and Macroptilium atropurpureum plants inoculated with isolates from Platypodium and 


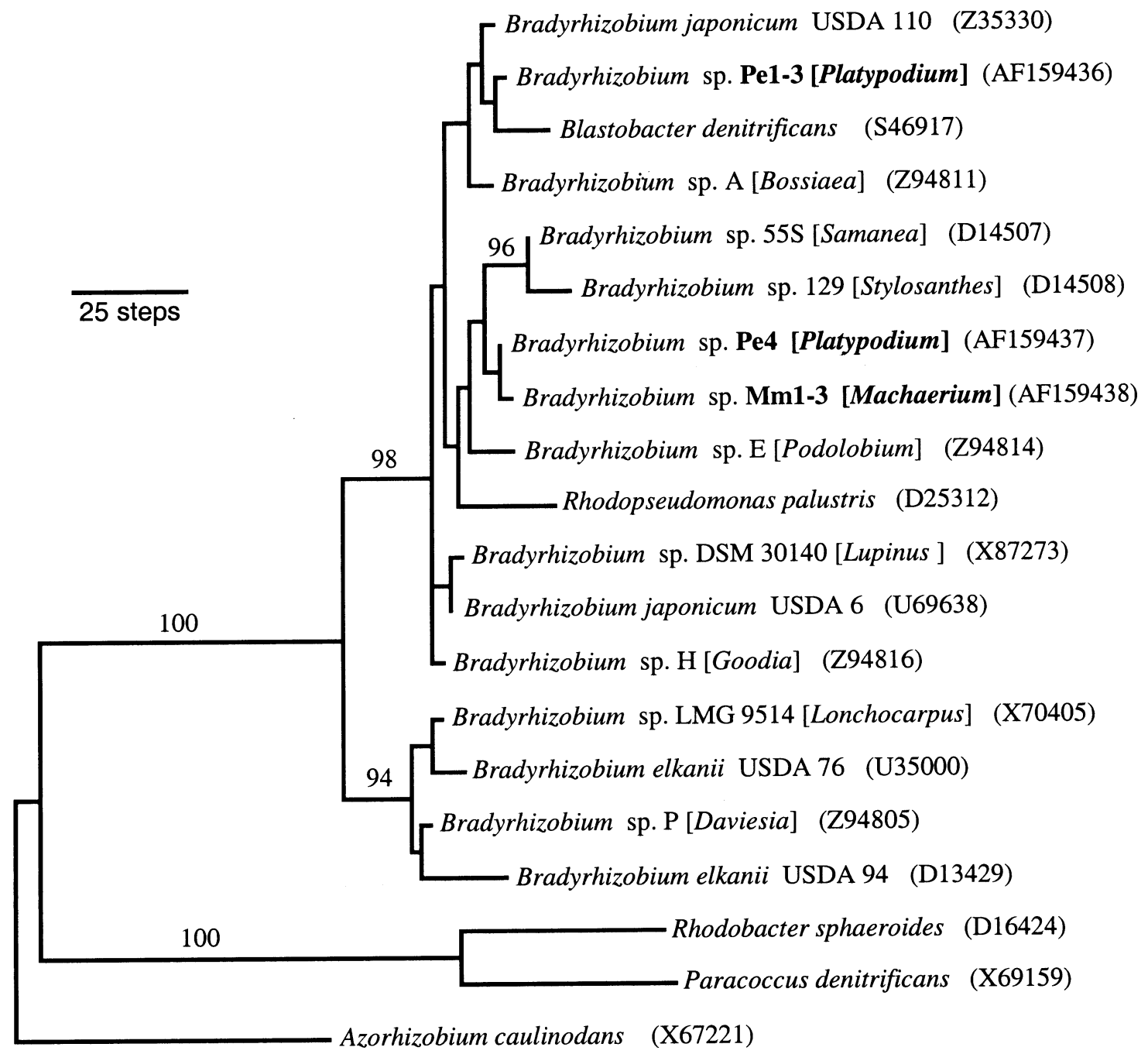

Fig. 3. Phylogeny of three Bradyrhizobium isolates from Platypodium and Machaerium (shown in bold) based on parsimony analysis of $16 \mathrm{~S}$ rRNA sequences. Numbers above branches are bootstrap percentages (based on 1000 replicates; for clarity, only bootstrap values $>80 \%$ are shown).

Machaerium (Fig. 4). Substantial acetylene reduction activity was evident in all combinations of plants and bacteria except those with isolate Mm1-3. This isolate formed smaller numbers of nodules on both hosts than any other isolate tested. This lower degree of nodulation compatibility was accompanied by a complete absence of measurable acetylene reduction activity for $V$. unguiculata nodules, and by relatively low activity for M. atropurpureum nodules (Fig. 4).

\section{DISCUSSION}

Our main finding was that root nodule bacteria associated with Platypodium and Machaerium in Panama constitute a diverse set of genotypes related to B. japonicum (Figs 2, 3). Bacterial genetic diversity was very high on a local scale. For each host legume species, divergent bacterial genotypes were found not only on separate plants growing $<2 \mathrm{~km}$ apart, but also among separate nodules on a single host individual (Table 1, Fig. 1)

This high diversity, coupled with the limited scale of sampling, means that it is not yet possible to reach conclusions about the degree of host specificity for many of the bacterial genotypes, since they were recovered only once or twice. In addition, there are numerous other potential legume host taxa sharing this environment (Croat, 1978) that have not yet been sampled. Thus, even for bacterial genotypes that seemed to be consistently associated with one host (e.g. ET1), much additional research will be required to understand host relationships. Nevertheless, certain genotypes clearly did not show strict specificity for Platypodium vs Machaerium, since they were recovered multiple times from both host taxa (Table 1, Fig. 1). Also, sequence analysis of a portion of $23 \mathrm{~S}$ rRNA indicated very close relationships of some isolates from Platypodium vs Machaerium (Fig. 2). Moreover, an 

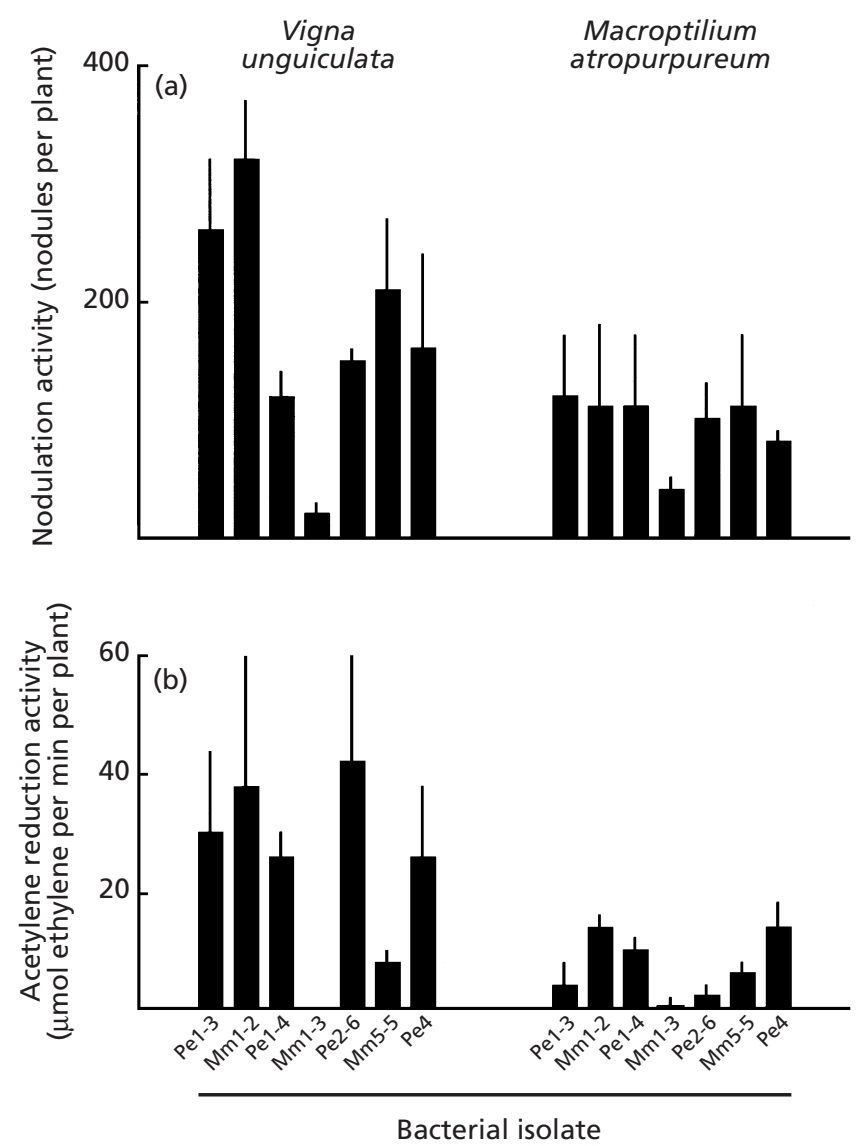

Fig. 4. Nodulation (a) and acetylene reduction activity (b) of $V$. unguiculata (left) and $M$. atropurpureum (right) inoculated with Bradyrhizobium isolates from Platypodium and Machaerium. Data shown are means + 1 SD.

inoculation experiment demonstrated that all of the isolates tested had potential host ranges that extended to other legume species as well (Fig. 4). Therefore, a lack of specificity toward Platypodium vs Machaerium would not be surprising.

The tree based on 16S rRNA sequence variation indicated that the Platypodium and Machaerium isolates apparently did not form a single phylogenetic group (Fig. 3). Instead, one Panama isolate exhibited a close relationship to the North American soybean symbiont $B$. japonicum USDA 110 , whilst two other isolates clustered with bradyrhizobia from other host legumes in the Philippines. As observed in previous analyses (Barrera et al., 1997; Laguerre et al., 1997), the 16S rRNA phylogeny showed a strongly marked division of the genus Bradyrhizobium into two basic lineages allied with $B$. japonicum vs $B$. elkanii. There was strong bootstrap support for placing the Panama isolates in the B. japonicum group (Fig. 3). However, the structure of relationships within the B. japonicum group was not clearly resolved by the $16 \mathrm{~S}$ rRNA data. Sets of apparently related sequences were marked by relatively small numbers of shared nucleotide substitutions, and bootstrap resampling analysis indicated that alternative hypotheses about relationships could not be ruled out with high confidence. Thus, a definitive resolution of phylogenetic relationships within this group will require additional sequence information from other, more rapidly evolving loci.

Research on 23S rRNA sequence variation in Bradyrhizobium isolates from temperate North America has suggested that isolates related to $B$. japonicum vs $B$. elkanii show a consistent length difference in the $5^{\prime}$ IVS region (Sterner \& Parker, 1999), which therefore may be useful for typing unknown bacteria. The present study suggests caution is advisable with regard to using length variation alone as a marker for relationships, unless validated by sequencing. Several Panama isolates had a $23 \mathrm{~S}$ rRNA length variant very similar to $B$. elkanii, but subsequent sequence analysis did not confirm a close relationship. Both B. elkanii and certain Panama isolates had two long deletions relative to the B. japonicum sequence, but the precise size and location for one of the deletions were not identical, and a parsimony tree instead grouped the Panama isolates together with B. japonicum (Fig. 2). Overall, the evidence currently available suggests that a short $23 \mathrm{~S}$ rRNA IVS region is a consistent trait of isolates related to B. elkanii (Sterner \& Parker, 1999; Parker, 1999). However, tropical bacteria related to $B$. japonicum are polymorphic for this same phenotype. Further analysis of this polymorphism, particularly its biogeographic distribution, would be valuable to better define the utility of the $23 \mathrm{~S}$ rRNA IVS region as a diagnostic tool.

In conclusion, our results provide new information about the diversity and relationships of root nodule bacteria for the legume genera Platypodium and Machaerium, whose bacterial symbionts had not been previously characterized in detail. Much additional research on bacteria associated with these and other genera of tropical forest legumes will be necessary to build a clear systematic understanding of the nodule bacteria in this environment.

\section{ACKNOWLEDGEMENTS}

We are grateful to C. Augspurger for suggestions about plant locations on BCI, to J. Pfeil for assistance with sequencing, and to L. D. Kuykendall for providing bacterial isolates. We also thank the Smithsonian Tropical Research Institute and the Republic of Panama's Instituto de Recursos Nacionales Renovables for permission to collect on BCI, the Harpur College Dean of Arts and Sciences for travel support, and the Howard Hughes Medical Institute for other financial support.

\section{REFERENCES}

Augspurger, C. K. (1983). Seed dispersal of the tropical tree, Platypodium elegans, and the escape of its seedlings from fungal pathogens. J Ecol 71, 759-771.

Barrera, L. L., Trujillo, M. E., Goodfellow, M., García, F. J., Hernández-Lucas, I., Dávila, G., van Berkum, P. \& MartínezRomero, E. (1997). Biodiversity of bradyrhizobia nodulating Lupinus spp. Int J Syst Bacteriol 47, 1086-1091. 
Bastos, M. D. (1988). Contributions to the systematic study of some species of the genus Machaerium (Leguminosae, Papilionoideae) occurring in Brazilian Amazonia. Bol Mus Para Emilio Goeldi Ser Bot 3, 183-278.

Brosius, J., Palmer, M. L., Kennedy, P. J. \& Noller, H. F. (1978). Complete nucleotide sequence of a $16 \mathrm{~S}$ ribosomal RNA gene from Escherichia coli. Proc Natl Acad Sci USA 75, 4801-4805.

Croat, T. B. (1978). Flora of Barro Colorado Island. Stanford, CA: Stanford University Press.

Dupuy, N., Willems, A., Pot, B. \& 7 other authors (1994). Phenotypic and genotypic characterization of bradyrhizobia nodulating the leguminous tree Acacia albida. Int $J$ Syst Bacteriol 44, 461-473.

Evguenieva-Hackenberg, E. \& Selenska-Pobell, S. (1995). Variability of the 5 -end of the large subunit rDNA and presence of a new short class of rRNA in Rhizobiaceae. Lett Appl Microbiol 21, 402-405.

de Faria, S. M., Franco, A. A., de Jesus, R. M., Menandro, M. de S., Baitello, J. B., Mucci, E. S. F., Dobereiner, J. \& Sprent, J. I. (1984). New nodulating legume trees from south east Brazil. New Phytol 98, 317-327.

Felsenstein, J. (1985). Confidence limits on phylogenies: an approach using the bootstrap. Evolution 39, 783-791.

Foster, R. B. \& Brokaw, N. V. L. (1996). Structure and history of the vegetation of Barro Colorado Island. In The Ecology of a Tropical Forest: Seasonal Rhythms and Long-term Changes, pp. 67-81. Edited by E. G. Leigh, A. S. Rand \& D. M. Windsor. Washington, DC: Smithsonian Institution Press.

Gentry, A. H. (1993). A Field Guide to the Families and Genera of Woody Plants of Northwestern South America (Columbia, Ecuador, Peru). Chicago, IL: University of Chicago Press.

Lafay, B. \& Burdon, J. J. (1998). Molecular diversity of rhizobia occurring on native shrubby legumes in southeastern Australia. Appl Environ Microbiol 64, 3989-3997.

Laguerre, G., van Berkum, P., Amarger, N. \& Prevost, D. (1997). Genetic diversity of rhizobial symbionts isolated from legume species within the genera Astragalus, Oxytropis, and Onobrychis. Appl Environ Microbiol 63, 4748-4758.

Oyaizu, H., Matsumoto, S., Minamisawa, K. \& Gamou, T. (1993). Distribution of rhizobia in leguminous plants as surveyed by phylogenetic identification. J Gen Appl Microbiol 39, 339-354.

Parker, M. A. (1999). Relationships of bradyrhizobia from the legumes Apios americana and Desmodium glutinosum. Appl Environ Microbiol 65, 4914-4920.

Parker, M. A. \& Wilkens, R. T. (1990). Effects of disease resistance genes on Rhizobium symbiosis in an annual legume. Oecologia 85, 137-141.

Raven, P. H. \& Polhill, R. M. (1981). Biogeography of the Leguminosae. In Advances in Legume Systematics, pp. 27-34. Edited by R. M. Polhill \& P. H. Raven. Kew: Royal Botanic Gardens.

Rudd, V. E. (1977). The genus Machaerium (Leguminosae) in Mexico. Bol Soc Bot Mexico 37, 119-146.

Saitou, N. \& Nei, M. (1987). The neighbor-joining method: a new method for reconstructing phylogenetic trees. Mol Biol Evol 4, 406-425.

Selander, R. K., Caugant, D. A., Ochman, H., Musser, J. M., Gilmour, M. N. \& Whittam, T. S. (1986). Methods of multilocus enzyme electrophoresis for bacterial population genetics and systematics. Appl Environ Microbiol 51, 873-884.

Selenska-Pobell, S. \& Evguenieva-Hackenberg, E. (1995). Fragmentations of the large-subunit rRNA in the family Rhizobiaceae. J Bacteriol 177, 6993-6998.

Sneath, P. H. A. \& Sokal, R. R. (1973). Numerical Taxonomy. San Francisco, CA: W. H. Freeman.

Soltis, D. E., Haufler, C. H., Darrow, D. C. \& Gastony, G. J. (1983). Starch gel electrophoresis of ferns: a compilation of grinding buffers, gel and electrode buffers, and staining schedules. Amer Fern $J$ 73, 9-27.

de Souza Moreira, F. M., de Silva, M. F. \& de Faria, S. M. (1992). Occurrence of nodulation in legume species in the Amazon region of Brazil. New Phytol 121, 563-570.

Spoerke, J. M., Wilkinson, H. H. \& Parker, M. A. (1996). Nonrandom genotypic associations in a legume-Bradyrhizobium mutualism. Evolution 50, 146-154

Sterner, J. P. \& Parker, M. A. (1999). Diversity and relationships of bradyrhizobia from Amphicarpeaea bracteata based on partial nod and ribosomal sequences. Syst Appl Microbiol 22, 387-392.

Thies, J. E., Bohlool, B. B. \& Singleton, P. W. (1991). Subgroups of the cowpea miscellany: symbiotic specificity within Bradyrhizobium spp. for Vigna unguiculata, Phaseolus lunatus, Arachis hypogaea, and Macroptilium atropurpureum. Appl Environ Microbiol 57, 1540-1545.

Thompson, J. D., Higgins, D. G. \& Gibson, T. J. (1994). CLUSTAL $\mathrm{W}$ : improving the sensitivity of progressive multiple sequence alignment through sequence weighting, position-specific gap penalties and weight matrix choice. Nucleic Acids Res 22, 4673-4680.

Turk, D. \& Keyser, H. H. (1992). Rhizobia that nodulate tree legumes: specificity of the host for nodulation and effectiveness. Can J Microbiol 38, 451-460.

Vincent, J. M. (1970). A Manual for the Practical Study of the Root-nodule Bacteria (International Biological Programme handbook no. 15). Oxford: Blackwell.

Wilkinson, H. H., Spoerke, J. M. \& Parker, M. A. (1996). Divergence in symbiotic compatibility in a legumeBradyrhizobium mutualism. Evolution 50, 1470-1477.

Willems, A. \& Collins, M. D. (1992). Evidence for a close genealogical relationship between Afipia (the causal organism of cat scratch disease), Bradyrhizobium japonicum and Blastobacter denitrificans. FEMS Microbiol Lett 96, 241-246.

Willems, A. \& Collins, M. D. (1993). Phylogenetic analysis of rhizobia and agrobacteria based on 16S rRNA gene sequences. Int J Syst Bacteriol 43, 305-313.

Wilson, K. (1993). Preparation of genomic DNA from bacteria. In Current Protocols in Molecular Biology, pp. 2.4.1-2.4.5. Edited by F. M. Ausubel, R. Brent, R. E. Kingston, D. D. Moore, J. G. Siedman, J. A. Smith \& K. Struhl. New York, NY: Wiley.

Wong, F. Y. K., Stackebrandt, E., Ladha, J. K., Fleischman, D. E., Date, R. A. \& Fuerst, J. A. (1994). Phylogenetic analysis of Bradyrhizobium japonicum and photosynthetic stem-nodulating bacteria from Aeschynomene species grown in separated geographic regions. Appl Environ Microbiol 60, 940-946.

Young, J. P. W. \& Haukka, K. E. (1996). Diversity and phylogeny of rhizobia. New Phytol 133, 87-94. 